UDC 577.615.28; 616.006.48

\title{
Cisplatin treatment of C6 rat glioma in vivo did not influence copy number alterations and growth pattern of tumor-derived resistant cells
}

\author{
A. A. Stepanenko', V. P. Baklaushev ${ }^{2,3}$, Y. S. Vassetzky ${ }^{4}$, V. V. Dmitrenko \\ ${ }^{1}$ Institute of Molecular Biology and Genetics, NAS of Ukraine \\ 150, Akademika Zabolotnoho Str., Kyiv, Ukraine, 03680 \\ 2 Pirogov Russian National Research Medical University, \\ 1, Ostrovitianov Str., Moscow, Russian Federation, 117997 \\ ${ }^{3}$ Federal Research and Clinical Centre, Federal Medical-Biological Agency \\ 28, Orekhoviy Blvd. Moscow, Russian Federation, 115682 \\ ${ }^{4}$ CNRS UMR 8126, Universit Paris-Sud 11, Institut Gustave Roussy \\ 114, rue Edouard Vaillant, Villejuif, France, 94805 \\ a.a.stepanenko@gmail.com
}

\begin{abstract}
Aim. To investigate whether the cisplatin treatment of C6 rat glioma in vivo impacts the copy number alterations (CNAs), proliferation and colony formation efficiency (CFE) of tumor-derived cisplatin-resistant cells. Methods. The glioma modeling was performed by means of intracerebral stereotactic implantation of rat glioma C6 cells into the striatum region of rats. The rats received $20 \%$ dimethyl sulfoxide DMSO (C6R1) or cisplatin (C6R4CIS and C6R5CIS) injected intraperitoneally ( $5 \mathrm{mg} / \mathrm{kg}$ ) three times per week. After 10 injections, gliomas were resected and the cells were cultured for in vitro analysis. CNAs were analyzed by array comparative genome hybridization, proliferation by direct cell counting in hemocytometer, CFE by soft agar assay. Results. No significant changes in the CNAs and CFE of cisplatin-treated rat glioma C6R4CIS and C6R5CIS cell lines were observed compared to the vehicle-treated control C6R1 cells. However, C6R5CIS but not C6R4CIS had a reduced proliferation. Interestingly, both cisplatin- and vehicle-treated brain-grown cells had a reduced proliferation and CFE in comparison to the parental C6 cells. Conclusions. Despite numerous reports on the destabilizing effects of cisplatin on genome and phenotype, the cisplatin treatment of C6 cells in vivo did not affect genome stability, CFE, and had an inconsistent effect on the proliferation in vitro. The rat brain microenvironment may potentially impact the growth characteristics of rat glioma cells.
\end{abstract}

Key words: aneuploidy, chromosome instability, drug resistance, tumor evolution, heterogeneity.

\section{Introduction}

Cisplatin (also called cisplatinum or cis-diamminedichloroplatinum(II) is a platinum inorganic coordination compound with a square planar geometry. It is chemically inert until one or both of its chloride atoms are displaced spontaneously by water molecules into the cytoplasm due to the relatively low concentration of chloride ions in the cytoplasm ver- sus the extracellular space. Mono-/bi-aquated forms of cisplatin are highly electrophilic and form covalent bonds with methionine and cysteine-containing peptides. Cisplatin binds with high affinity to DNA, especially to nucleophilic N7 sites on purines, promoting the formation of protein-DNA complexes as well as intra- and inter-strand DNA adducts. Thus, cisplatin exerts its cytostatic/cytotoxic effects in both nuclear and cytoplasmic compartments with the pri-

\footnotetext{
(C) 2015 A. A. Stepanenko et al.; Published by the Institute of Molecular Biology and Genetics, NAS of Ukraine on behalf of Biopolymers and Cell. This is an Open Access article distributed under the terms of the Creative Commons Attribution License (http://creativecommons.org/licenses/by/4.0/), which permits unrestricted reuse, distribution, and reproduction in any medium, provided the original work is properly cited
} 
mary role of the latter as high cytotoxicity was observed in enucleated cells [1-2] The cisplatin treatment resulted in the inhibition of mitochondrial respiration and efflux of calcium from the mitochondria, induced endoplasmic reticulum stress, reactive oxygen species formation and oxidative stress, leading to the depletion of reduced glutathione (GSH) and nicotinamide adenine dinucleotide (NADH) and peroxidation of polyunsaturated lipids and proteins (reviewed in [1, 2]).

Cisplatin has been used in clinics since the 70 s of the XX century for the treatment of multiple types of solid cancers. Noteworthy, cisplatin is significantly efficient only against germ cell cancers, resulting in a durable complete remission in $>80 \%$ of the patients; the biological reasons of this are still not completely understood. In contrast, the clinical response elicited by cisplatin in the patients affected by other solid tumors is very temporary, and the use of cisplatin-based chemotherapeutic regimens is restricted due to intrinsic or acquired resistance as well as considerable systemic side effects $[1,2]$.

The glioma clinical trials also demonstrated a low efficacy or even inferior outcome in the high-grade glioma patients after the treatment with cisplatin-based chemotherapy. On the contrary, the in vivo models showed that the treatment with cisplatin or cisplatin-loaded $\mathrm{mAbCx} 43$ - or BSAT1-conjugated nanogels significantly inhibited rat glioma C6 and 101/8 tumor growth and increased survival of animals [3, 4]. Similarly, a combination of cisplatin with other therapeutic approaches demonstrated a high inhibitory effect in the in vivo glioma models [5-7]. The reason for this obvious discrepancy is that the drugmediated stress may actually foster the tumor evolution by both selecting genetic variations and generating novel variations through the induction of genome reorganization [8-13]. An increase in chromosomal aberrations during and after chemotherapy was found to associate with an increased tumor aggressiveness [9]. The ability of cisplatin to induce chromosome abnormalities has been known since the time of its approval for the clinic use [14]. For example, the cisplatin treatment induced a significant increase in the chromosome breakage at all stages of spermatogenesis in Drosophila melanogaster [15]. In Saccharomyces cerevisiae, the cisplatin treatment induced chromosomal aberrations, although the degree of instability was lower than that induced by other DNA damaging agents (e.g., bleomycin, camptothecan, or $\gamma$-irradiation) [16]. A comparison of the parental human ovarian cancer cells to sublines selected for resistance to cisplatin revealed that the acquired resistance to cisplatin was associated with the numerical and structural chromosome aberrations and substantial copy number alterations (CNAs) $[17,18]$.

The intrinsic or acquired resistance is another significant contributor to the therapy failure. The cell culture models revealed that cisplatin resistance is attained by several complex molecular and cellular mechanisms. They include but are not confined to the activation of multiple signal transduction pathways, reduction of cisplatin accumulation by either active efflux or impaired influx, detoxification by cellular antioxidant systems, increase in DNA damage repair, inactivation of apoptosis pathway, alterations of the membrane protein trafficking due to the cytoskeleton defective organization, activation of the epithelial-mesenchymal transition, overexpression of chaperones, deregulation of miRNA and transcription factors, the impact of stroma cells and components of extracellular matrix $[1,2,19]$. An overall abnormal phenotype after the cisplatin treatment results from an increase in DNA mutation load and profound changes in the DNA methylome, transcriptome, proteome, metabolome and kinome (kinase activity profile) [20]. Altogether, these data reveal a complex multilevel mechanism of tumor cells self-defence against the cisplatin cytotoxicity.

Here, we have investigated whether the cisplatin treatment of $\mathrm{C} 6$ rat glioma in vivo impacted CNAs, proliferation and colony formation efficiency (CFE) of the tumor-derived cisplatin-resistant cells in vitro.

\section{Materials and Methods}

\section{Cell lines}

Rat glioma C6 cell line was grown in DMEM (Hy Clone, Thermo Scientific, UK) supplemented with 
$10 \%$ FBS (HyClone, Thermo Scientific) and $100 \mu \mathrm{g} /$ $\mathrm{ml}$ penicillin/100 $\mathrm{u} / \mathrm{ml}$ streptomycin (Sigma, USA) in the environment of $95 \%$ air $/ 5 \% \mathrm{CO}_{2}$.

\section{Cisplatin treatment of rats} with intracranial C6 gliomas

The animals were kept and treated in accordance with the Guidelines on Laboratory Practices adopted by the Ministry of Health of the Russian Federation (Order 267, 19 June 2003), and the principles of bioethics adopted by the European Convention for the Protection of Vertebrate Animals Used for Experimental and Other Scientific Purposes (Strasbourg, 1986). A glioma modeling and tumor volume measurement were performed as described previously [3, 4]. After five days of C6 glioma cells inoculation, rats received $20 \%$ DMSO ( $\mathrm{n}=1$, namely C6R1), which served as a solvent for drug, or cisplatin $(\mathrm{n}=2$, namely C6R4CIS and C6R5CIS) injected intraperitoneally three times per week at a dose of $5 \mathrm{mg} / \mathrm{kg}$. Rats were sacrificed after 10 injections of cisplatin/ DMSO. Gliomas were harvested aseptically and disaggregated mechanically. The cell suspension was seeded on plates with growth medium. Cells were used at passage numbers 3-10 for analysis.

\section{Array comparative genome hybridization (aCGH)}

Total DNA was isolated using NucleoSpin Blood DNA extraction kit (Macherey-Nagel, Germany) according to the manufacturer's instructions. DNA quality was assessed using NanoDrop 1000 Spectrophotometer (Thermo Scientific, USA). aCGH was performed as detailed previously [12]. Rat cell lines were analyzed on $180 \mathrm{~K}$ microarray (Agilent Technologies, Santa Clara, CA, USA). Image analysis was carried out with Agilent CytoGenomics, edition 2.9.2.4 (Agilent).

\section{Cell proliferation analysis}

Cells were seeded onto $6 \mathrm{~cm}$ dishes at the density $1 \times$ $\times 10^{4}$ and grown in the high-glucose DMEM with $10 \%$ FBS. On the 7 th day of seeding, medium was carefully removed; cells were washed with PBS, trypsinized, harvested, incubated with trypan blue, and calculated using a hemocytometer. The test was repeated at least three times.

\section{Soft agar colony formation assay}

$5 \times 10^{3}$ cells were placed in $1.5 \mathrm{ml}$ of $0.35 \% / 10 \%$ FBS/DMEM low gelling temperature agarose (Gibco, Life Technologies, Grand Island, USA) with
C6R1

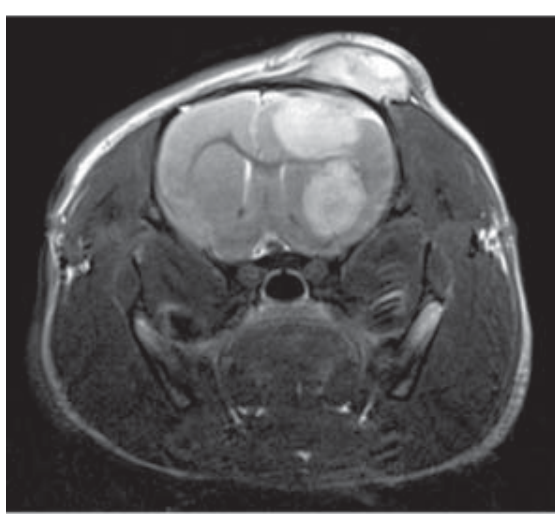

C6R4CIS

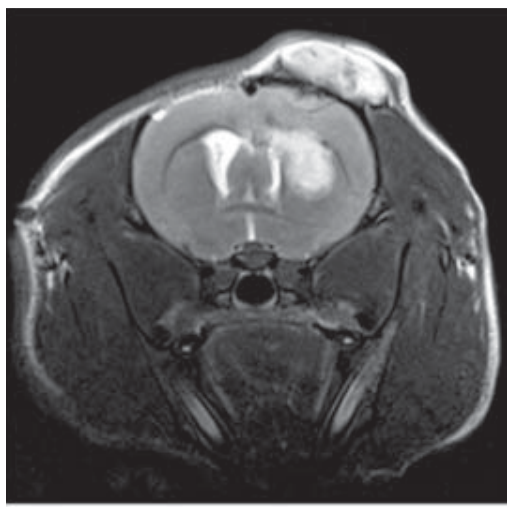

C6R5CIS

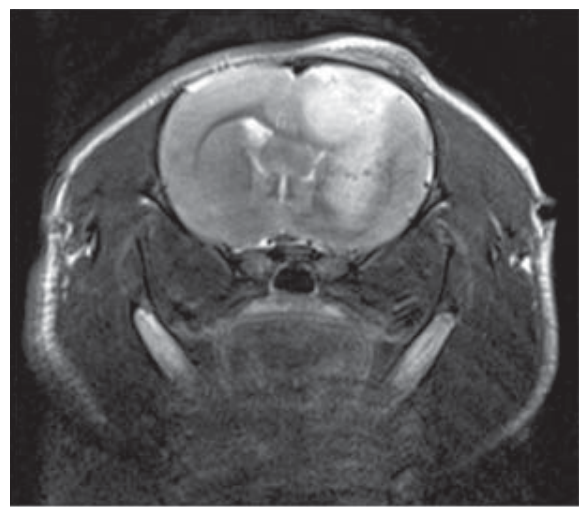

Fig. 1. Brain magnetic resonance imaging (MRI) using a ClinScan MRI scanner with field strength of 7T was carried out for C6 rat gliomas after 2 weeks of cisplatin treatment. A morphometric analysis of C6 gliomas after this period of time showed that tumor volumes of C6R1, C6R4CIS and C6R5CIS gliomas were $\approx 80 \mathrm{~mm}^{3}, \approx 35 \mathrm{~mm}^{3}$ and $\approx 60 \mathrm{~mm}^{3}$, respectively. Rats with C6 gliomas received cisplatin at a dose of $5 \mathrm{mg} / \mathrm{kg}$ (C6R4CIS and C6R5CIS) or 20\% DMSO (control C6R1), injected intraperitoneally three times per week. The animals were sacrificed after 10 injections of cisplatin/DMSO 


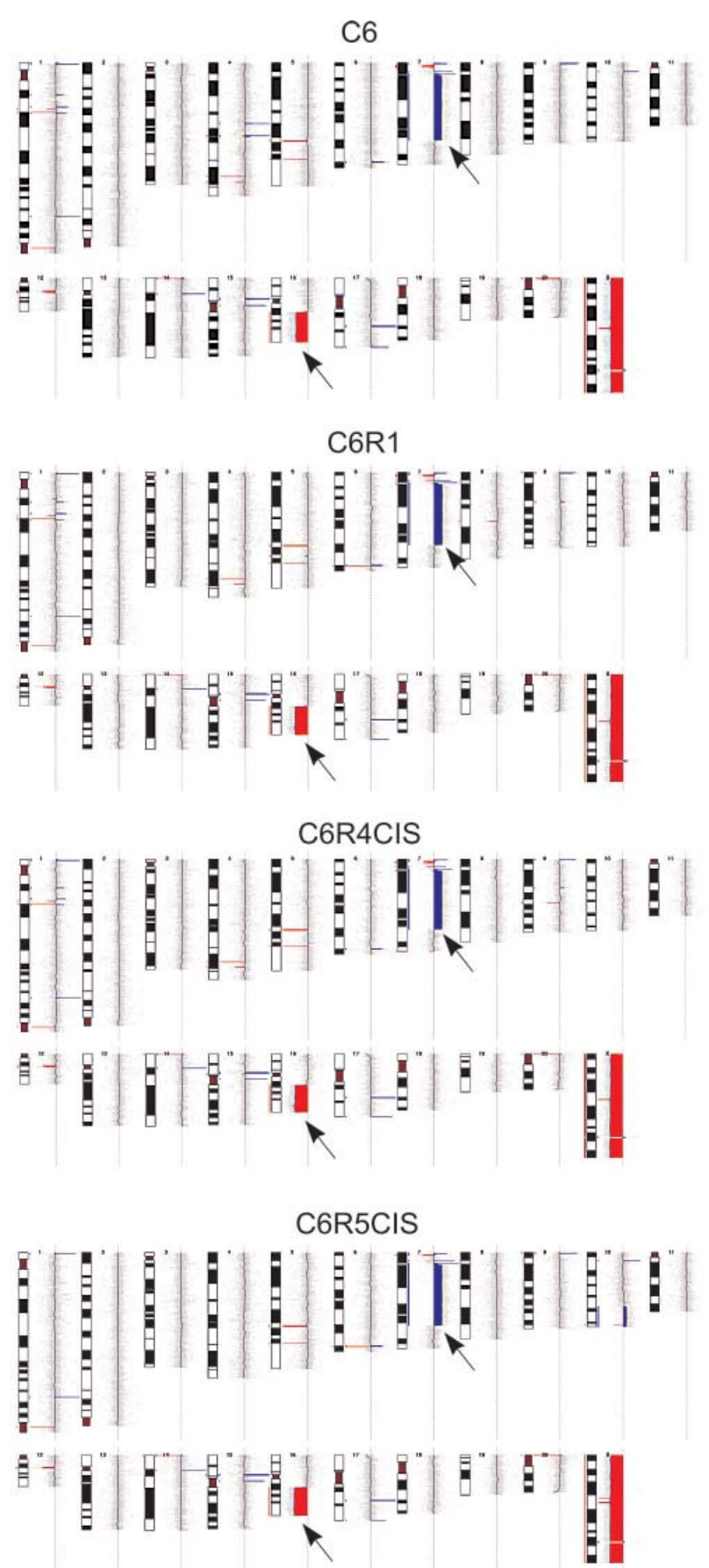

Fig. 2. Chromosomal ideograms with the drawn color bars aligned along chromosomes show the areas of genetic gain/loss. Red bars represent areas of copy number loss, whereas blue bars represent areas of copy number gain. The major detected aberrations were loss of 16q12.1-q24.3 and gain of 7p21.1-q31.1 (marked by arrows). CNAs were identified by array comparative genome hybridization (aCGH)
DMEM supplemented with $10 \%$ FBS. $0.35 \%$ top agarose was poured on $1.5 \mathrm{ml}$ of solidified $0.5 \%$ base agarose $/ 10 \%$ FBS/DMEM. Cells were seeded in triplicates in 35-mm dishes of 6-well plates and grown at $37^{\circ} \mathrm{C}$ for three weeks to allow colony formation. Colonies were visualized by staining with $0.005 \%$ crystal violet, photographed, and counted using OpenCFU software [21]. Test for each cell line was repeated three times.

\section{Statistics}

The Student's t-test was used to analyze the significance of variability between the results of each group and its corresponding control (Statistica 7 Software, San Diego, USA). Results with $* \mathrm{P}<0.05, * * \mathrm{P}<$ $<0.01$, and $* * * \mathrm{P}<0.001$ were considered significant. All experimental data are reported as the mean and the error bars represent the experimental standard error ( \pm standard deviation, $S D)$.

\section{Results and Discussion}

Cisplatin-treated C6R4CIS, C6R5CIS and vehicletreated control C6R1 cell lines were established from the parental C6 cell line by injecting cisplatin (or a vehicle $20 \%$ DMSO) intraperitoneally three times per week at a dose of $5 \mathrm{mg} / \mathrm{kg}$. A morphometric analysis of C6 gliomas after two weeks of treatment showed that tumor volumes of C6R1, C6R4CIS and C6R5CIS gliomas were $\approx 80 \mathrm{~mm}^{3}, \approx 35 \mathrm{~mm}^{3}$ and $\approx 60 \mathrm{~mm}^{3}$, respectively (Figure 1). After 10 injections, the vehicle-treated control and surviving cisplatin-resistant cells were tumor-derived and analyzed in vitro. Despite the numerous reports on genotoxic effects of cisplatin $[2,15-18,22]$, the copy number alterations (CNAs) of parental C6 cells, control C6R1, and cisplatin-treated C6R4CIS and C6R5CIS cell lines were essentially similar with minor variations in the genedepleted chromosome loci. The major detected aberrations were loss of 16q12.1-q24.3 and gain of 7p21.1-q31.1 (Figure 2). It should be noted that in contrast to conventional cytogenetics/karyotyping, $\mathrm{aCGH}$ is based on the average profile of genetic changes in thousands of cells; this underestimates structural chromosome complexity and heterogeneity of tumor cells $[12,23]$. 
There was no difference in proliferation rates between C6R1 and C6R4CIS; however, C6R5CIS had a moderately reduced proliferation (Figure 3). Further, no difference in CFE between C6R1 and C6 R4CIS or C6R5CIS cells was observed (Figure 4). The data that cisplatin treatment reduces tumor growth and increases survival of C6 glioma-bearing rats [4] but does not obviously influence chromosome stability and in vitro growth characteristics of C6 cells, which survived/resisted cisplatin treatment, suggest that cisplatin has a cytostatic rather than profound genotoxic and cytotoxic effects on C6 cells in vivo. Interestingly, we have observed reduced proliferation and CFE of the control and cisplatin-treated cells in comparison to the parental C6, suggesting that the rat brain microenvironment may select for slow-dividing C6 cells. The alternative explanation is that in brain, C6 cells are adapted to different nutrients, oxygen levels, growth-stimulating and other factors; therefore they undergo a stress when reintroduced to in vitro culture. Finally, we cannot exclude an effect of a vehicle (20\% DMSO) as DMSO treatment in vivo induced cytotoxicity at certain concentrations ([24] and refs. herein). However, we have injected substantially lower DMSO volume and concentration than those used in these studies.

Previously, we and others have shown that cisplatin or combination of cisplatin with other therapeutic approaches demonstrated a high inhibitory effect in in vivo models, including rat glioma C6 and 101/8 tumor models [3-7]. Unfortunately, the encouraging laboratory observations do not agree with the efficiency of treatment of the high-grade glioma patients. There were many frustrated clinical trials as exemplified below that ultimately did not justify the addition of cisplatin to the chemotherapeutic regimen of the high-grade glioma patient treatment. Cisplatin and carmustine followed by radiation did not improve median survival, survival at one year, or time-to-progression of patients with newly diagnosed glioblastoma. Furthermore, this treatment was associated with more serious toxicities than standard therapy [25]. Similarly, cisplatin administered concurrently with carmustine and radiotherapy resulted in a higher toxicity but provided no significant im-

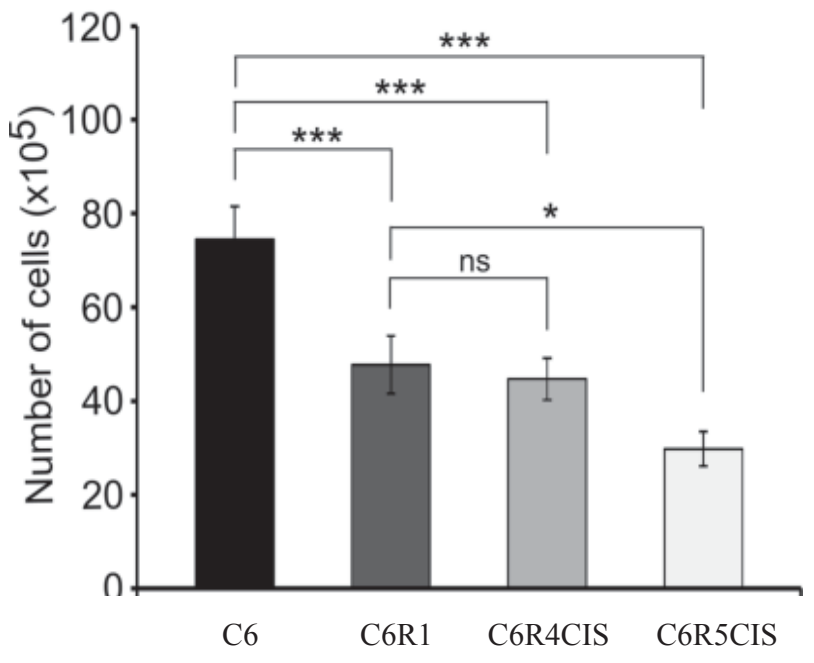

Fig. 3. Cisplatin treatment of C6 glioma in vivo did not consistently affect proliferation of tumor-derived C6 cells. However, significantly reduced proliferation of control C6R1 and cisplatin-treated C6R4CIS and C6R5CIS cell lines in comparison to parental C6 was observed. To analyze the rate of proliferation, cells were seeded at the density $1 \times 10^{4}$ cells. The number of cells was calculated after 7 days of growth. All experiments were performed at least three times and results are presented as the means \pm SD. ${ }^{*} \mathrm{P}<0.05,{ }^{*} * \mathrm{P}<0.001, \mathrm{NS}=$ non-significant

provement in survival [26]. The estimation of response rate, the rate of disease stabilization, and the probability of one-year survival of the patients with high-grade glioblastomas who received radiotherapy concurrently with cisplatin/carmustine chemotherapy did not support the routine use of concurrent cisplatin and carmustine [27]. The progression-free survival and overall survival of glioblastoma patients treated with the radiotherapy, cisplatin and carmustine were comparable with those obtained with the radiotherapy and temozolomide but the toxicity was more frequent and persistent. The results argued against future use of this combination in the treatment of patients with glioblastoma [28]. Although the median survival time with the cisplatin/nimustine neoadjuvant chemotherapy followed by the radiotherapy and adjuvant temozolomide was increased in patients with newly diagnosed glioblastoma, a high frequency of serious hematological toxicity limited its use [29]. Further, none real advantage of neoadjuvant cisplatin and etoposide after surgery 

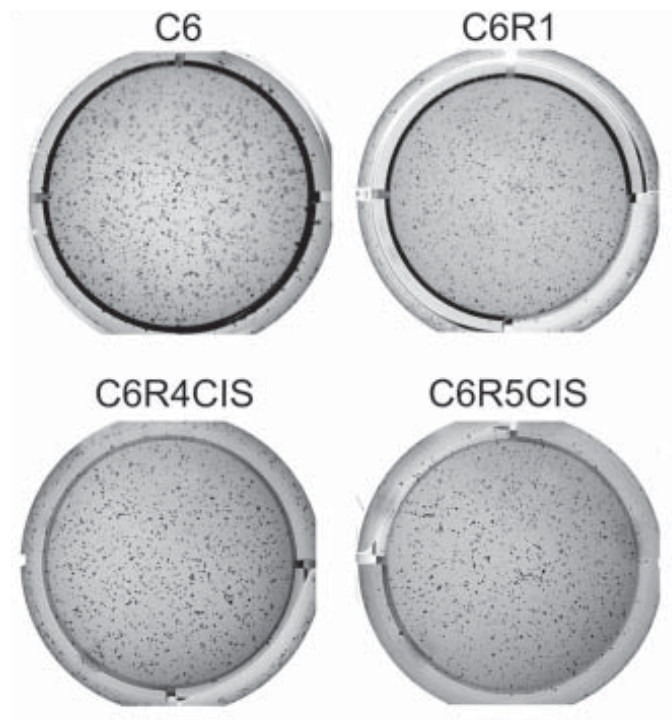

A

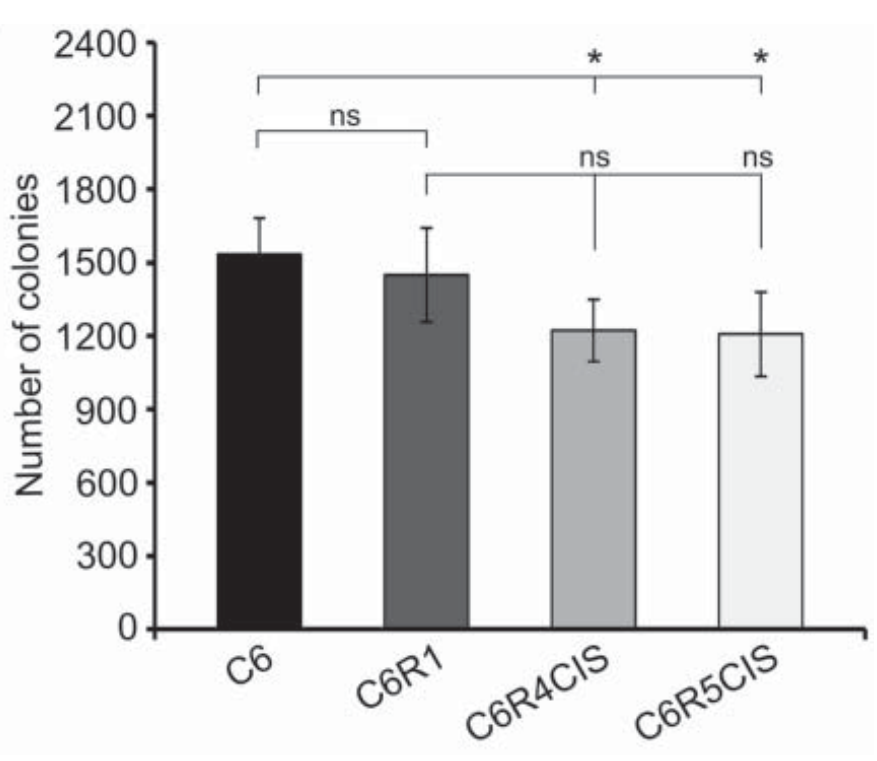

B

Fig. 4. Cisplatin treatment of C6 glioma in vivo did not affect colony formation efficiency (CFE) in soft agar of tumor-derived C6 cells. However, reduced CFE of control C6R1 and cisplatin-treated C6R4CIS and C6R5CIS cell lines in comparison to parental C6 was observed. For colony formation, $5 \times 10^{3}$ cells were seeded in soft agar and grown for 3 weeks. Colonies were stained with crystal violet and calculated using OpenCFU software. (A) The representative photographs of plate wells with stained colonies are shown. (B) The graph compares CFE of the designated cell lines. All experiments were performed three times and results are presented as the means $\pm \mathrm{SD}$. ${ }^{*} \mathrm{P}<0.05, \mathrm{NS}=$ non-significant

and prior to radical radiotherapy was obtained in the treatment of high-grade gliomas if compared with the standard adjuvant chemotherapy [30]. Cisplatin combined with cytosine arabinoside and hydroxyurea did not improve the six-month survival rate in patients with relapsed or progressive high-grade glioblastomas. Significant hematological toxicities were observed [31]. Finally, the recent medulloblastoma trial demonstrated that the cumulative cisplatin dose was not associated with overall survival [32].

Recently, we have shown that the long-term treatment of tumor cell lines with a DNA damaging drug temozolomide, which is widely used for glioma patients, promoted the clonal and non-clonal chromosome aberrations, CNAs and diverse phenotype changes affecting survival, CFE, migration, and invasion ([12], Stepanenko et al., in preparation). Furthermore, many chemotherapeutics, which have been used previously or are exploited currently in clinic for cancer treatment, were evidenced to induce/promote the chromosome instability/aneuploi- dy in rodent and human cells. These include nocodazole, a microtubule-depolymerizing agent; paclitaxel and taxol, microtubule-stabilizing agents; platinum compounds cisplatin and carboplatin; etoposide and doxorubicin, topoisomerase I and II inhibitors; bleomycin that causes breaks in DNA; actinomycin D which interferes with transcription and replication; 5-fluorouracil, a thymidylate synthase inhibitor; imatinib and nilotinib, multiple kinase inhibitors; rapamycin, an mTOR inhibitor; tamoxifen, an estrogen receptor inhibitor, and many others (reviewed in [9]). This should be seriously taken into account as the cancer cell genome instability, promoted by drug-mediated system stress, fosters genomic, epigenetic, and non-genetic heterogeneity, intensifies profound transcriptome and proteome changes, and rewires metabolic and signaling network, altogether, giving rise to the diverse drug-resistant phenotype variants. The genome instability significantly correlates with inherent and acquired multi-drug resistance, and chemoresistance acquisition is accompa- 
nied by newly evolved chromosome imbalances (reviewed in [8-11, 13, 33-38]).

\section{Conclusion}

Despite the numerous reports on genome and phenotype destabilizing effects of cisplatin, we have not observed any changes in CNAs, CFE and consistent changes in proliferation in vitro of in vivo cisplatintreated rat glioma C6 cells. However, we have revealed that brain-grown $\mathrm{C} 6$ cells have a reduced proliferation rate and $\mathrm{CFE}$ in comparison to the parental $\mathrm{C} 6$ cell adapted to grow in vitro for decades. The versatile complex mechanisms of intrinsic/acquired resistance and considerable systematic side effects significantly reduce the efficacy of cisplatin in clinic. The failure of phase II and III clinical trials with the cisplatin-based therapeutic regimens does not support the use of cisplatin in further high-grade glioma trials.

\section{Funding}

This work was partially supported by National Academy of Sciences of Ukraine (NASU) in frames of the program «Fundamental grounds of molecular and cell biotechnologies» (2010-2014) [grant number 38/14] and grant F1 «Human pathologies: from molecular to cellular events».

\section{REFERENCES}

1. Dasari S, Tchounwou PB. Cisplatin in cancer therapy: molecular mechanisms of action. Eur J Pharmacol. 2014;740: 364-78.

2. Galluzzi L, Vitale I, Michels J, Brenner C, Szabadkai G, Harel-Bellan A, Castedo M, Kroemer G. Systems biology of cisplatin resistance: past, present and future. Cell Death Dis. 2014;5:e1257.

3. Baklaushev VP, Nukolova NN, Khalansky AS, Gurina OI, Yusubalieva GM, Grinenko NP, Gubskiy IL, Melnikov PA, Kardashova KSh, Kabanov AV, Chekhonin VP. Treatment of glioma by cisplatin-loaded nanogels conjugated with monoclonal antibodies against Cx43 and BSAT1. Drug Deliv. 2015;22(3):276-85.

4. Nukolova NV, Baklaushev VP, Abakumova TO, Mel'nikov PA, Abakumov MA, Yusubalieva GM, Bychkov DA, Kabanov AV, Chekhonin VP. Targeted delivery of cisplatin by connexin 43 vector nanogels to the focus of experimental glioma C6. Bull Exp Biol Med. 2014;157(4):524-9.

5. Dorigo O, Turla ST, Lebedeva S, Gjerset RA. Sensitization of rat glioblastoma multiforme to cisplatin in vivo following restoration of wild-type p53 function. J Neurosurg. 1998;88 (3):535-40.

6. Messina S, Leonetti C, De Gregorio G, Affatigato V, Ragona G, Frati L, Zupi G, Santoni A, Porcellini A. Ras inhibition amplifies cisplatin sensitivity of human glioblastoma. Biochem Biophys Res Commun. 2004;320(2):493-500.

7. Redjal N, Zhu Y, Shah K. Combination of systemic chemotherapy with local stem cell delivered S-TRAIL in resected brain tumors. Stem Cells. 2015;33(1):101-10.

8. Horne SD, Stevens JB, Abdallah BY, Liu G, Bremer SW, Ye $\mathrm{CJ}$, Heng $\mathrm{HH}$. Why imatinib remains an exception of cancer research. J Cell Physiol. 2013;228(4):665-70.

9. Stepanenko AA, Kavsan VM. Evolutionary karyotypic theory of cancer versus conventional cancer gene mutation theory. Biopolym Cell. 2012; 28(4):267-80.

10. Duesberg P, Li R, Sachs R, Fabarius A, Upender MB, HehImann $R$. Cancer drug resistance: the central role of the karyotype. Drug Resist Updat. 2007;10(1-2):51-8.

11. Stepanenko AA, Kavsan VM. Karyotypically distinct U251, U373, and SNB19 glioma cell lines are of the same origin but have different drug treatment sensitivities. Gene. 2014; 540(2):263-5.

12. Stepanenko A, Andreieva S, Korets K, Mykytenko D, Huleyuk $N$, Vassetzky Y, Kavsan V. Step-wise and punctuated genome evolution drive phenotype changes of tumor cells. Mutat Res. 2015;771:56-69.

13. Liu G, Stevens JB, Horne SD, Abdallah BY, Ye KJ, Bremer $S W$, Ye CJ, Chen DJ, Heng HH. Genome chaos: survival strategy during crisis. Cell Cycle. 2014;13(4):528-37.

14. Roberts JJ, Friedlos F. Quantitative estimation of cisplatininduced DNA interstrand cross-links and their repair in mammalian cells: relationship to toxicity. Pharmacol Ther. 1987; 34(2):215-46.

15. Brodberg RK, Lyman RF, Woodruff RC. The induction of chromosome aberrations by cis-platinum(II) diamminodichloride in Drosophila melanogaster. Environ Mutagen. 1983; 5(3):285-97.

16. Myung K, Kolodner RD. Induction of genome instability by DNA damage in Saccharomyces cerevisiae. DNA Repair (Amst). 2003;2(3):243-58.

17. Wasenius VM, Jekunen A, Monni O, Joensuu H, Aebi S, Howell SB, Knuutila S. Comparative genomic hybridization analysis of chromosomal changes occurring during development of acquired resistance to cisplatin in human ovarian carcinoma cells. Genes Chromosomes Cancer. 1997; 18(4): 286-91.

18. Prasad M, Bernardini M, Tsalenko A, Marrano P, Paderova J, Lee CH, Ben-Dor A, Barrett MT, Squire JA. High definition cytogenetics and oligonucleotide aCGH analyses of cisplatin-resistant ovarian cancer cells. Genes Chromosomes Cancer. 2008;47(5):427-36.

19. Shen DW, Pouliot LM, Hall MD, Gottesman MM. Cisplatin resistance: a cellular self-defense mechanism resulting from 
multiple epigenetic and genetic changes. Pharmacol Rev. 2012;64(3):706-21.

20. Gabbiani C, Magherini F, Modesti A, Messori L. Proteomic and metallomic strategies for understanding the mode of action of anticancer metallodrugs. Anticancer Agents Med Chem. 2010;10(4):324-37.

21. Geissmann Q. OpenCFU, a new free and open-source software to count cell colonies and other circular objects. PLOS One. 2013;8(2):e54072.

22. Grundei T, Vogelsang H, Ott K, Mueller J, Scholz M, Becker $K$, Fink U, Siewert JR, Höfler H, Keller G. Loss of heterozygosity and microsatellite instability as predictive markers for neoadjuvant treatment in gastric carcinoma. Clin Cancer Res. 2000;6(12):4782-8.

23. Heng HH, Liu G, Stevens JB, Bremer SW, Ye KJ, Abdallah $B Y$, Horne SD, Ye CJ. Decoding the genome beyond sequencing: the new phase of genomic research. Genomics. 2011;98(4):242-52.

24. Galvao J, Davis B, Tilley M, Normando E, Duchen MR, Cordeiro MF. Unexpected low-dose toxicity of the universal solvent DMSO. FASEB J. 2014;28(3):1317-30.

25. Grossman SA, O’Neill A, Grunnet M, Mehta M, Pearlman JL, Wagner H, Gilbert M, Newton HB, Hellman R; Eastern Cooperative Oncology Group. Phase III study comparing three cycles of infusional carmustine and cisplatin followed by radiation therapy with radiation therapy and concurrent carmustine in patients with newly diagnosed supratentorial glioblastoma multiforme: Eastern Cooperative Oncology Group Trial 2394. J Clin Oncol. 2003;21(8):1485-91.

26. Buckner JC, Ballman KV, Michalak JC, Burton GV, Cascino TL, Schomberg PJ, Hawkins RB, Scheithauer BW, Sandler HM, Marks RS, O'Fallon JR; North Central Cancer Treatment Group 93-72-52; Southwest Oncology Group 9503 Trials. Phase III trial of carmustine and cisplatin compared with carmustine alone and standard radiation therapy or accelerated radiation therapy in patients with glioblastoma multiforme: North Central Cancer Treatment Group 93-7252 and Southwest Oncology Group 9503 Trials. J Clin Oncol. 2006;24(24):3871-9.

27. Blumenthal DT, Rankin C, Eyre HJ, Livingston RB, Spence AM, Stelzer KJ, Rushing EJ, Berger MS, Rivkin SE, Cohn AL, Petersdorf $\mathrm{SH}$. External beam irradiation and the combination of cisplatin and carmustine followed by carmustine alone for the treatment of high-grade glioma: a phase 2 Southwest Oncology Group trial. Cancer. 2008;113(3):559-65.

28. Silvani A, Gaviani P, Lamperti EA, Eoli M, Falcone C, Dimeco F, Milanesi IM, Erbetta A, Boiardi A, Fariselli L, Salmaggi $A$. Cisplatinum and $\mathrm{BCNU}$ chemotherapy in primary glioblastoma patients. J Neurooncol. 2009;94(1):57-62.

29. Kim IH, Park CK, Heo DS, Kim CY, Rhee CH, Nam DH, Lee SH, Han JH, Lee SH, Kim TM, Kim DW, Kim JE, Paek SH, Kim DG, Kim IA, Kim YJ, Kim JH, Park BJ, Jung HW. Radiotherapy followed by adjuvant temozolomide with or without neoadjuvant ACNU-CDDP chemotherapy in newly diagnosed glioblas- tomas: a prospective randomized controlled multicenter phase III trial. J Neurooncol. 2011;103 (3):595-602.

30. Díaz R, Jordá MV, Reynés G, Aparicio J, Segura A, Amador $R$, Calderero V, Beltrán A. Neoadjuvant cisplatin and etoposide, with or without tamoxifen, prior to radiotherapy in high-grade gliomas: a single-center experience. Anticancer Drugs. 2005;16(3):323-9.

31. Swinnen LJ, Rankin C, Carraway H, Albain KS, Townsend JJ, Budd GT, Kish JA, Rivkin SE, Blumenthal DT. A phase II study of cisplatin preceded by a 12 -h continuous infusion of concurrent hydroxyurea and cytosine arabinoside (Ara-C) for adult patients with malignant gliomas (Southwest Oncology Group S9149). J Neurooncol. 2008;86(3):353-8.

32. Nageswara Rao AA, Wallace DJ, Billups C, Boyett JM, Gajjar A, Packer RJ. Cumulative cisplatin dose is not associated with event-free or overall survival in children with newly diagnosed average-risk medulloblastoma treated with cisplatin based adjuvant chemotherapy: report from the Children's Oncology Group. Pediatr Blood Cancer. 2014; 61(1):102-6.

33. Duesberg P, Li R, Fabarius A, Hehlmann R. The chromosomal basis of cancer. Cell Oncol. 2005;27(5-6):293-318.

34. Stepanenko, Kavsan VM. Immortalization and malignant transformation of Eukaryotic cells. Cytol Genet. 2012; 46(2): 96-129.

35. Stepanenko AA, Vassetzky YS, Kavsan VM. Antagonistic functional duality of cancer genes. Gene. 2013;529(2):199-207.

36. Stepanenko A, Kavsan V. Cancer genes and chromosome instability. In: Oncogene and cancer - from bench to clinic. Rijeka: InTech Publisher, 2013. 496 p.

37. Stevens JB, Abdallah BY, Liu G, Ye CJ, Horne SD, Wang G, Savasan S, Shekhar M, Krawetz SA, Hüttemann M, Tainsky MA, Wu GS, Xie Y, Zhang K, Heng HH. Diverse system stresses: common mechanisms of chromosome fragmentation. Cell Death Dis. 2011;2:e178.

38. Duesberg P, Mandrioli D, McCormack A, Nicholson JM. Is carcinogenesis a form of speciation? Cell Cycle. 2011;10 (13):2100-14.

Терапія цисплатином клітин С6 гліоми щура in vivo не вплинула на зміни числа копій хромосомних локусів та патерн росту виділених з пухлини резистентних клітин

О. А. Степаненко, В. П. Баклаушев, Є. С. Васецький, В. В. Дмитренко

Мета. Перевірити, чи впливає терапія цисплатином клітин С6 гліоми щура in vivo на зміни числа копій хромосомних локусів, проліферацію і ефективність формування колоній цисплатин-нечутливими клітинами. Методи. Моделювання гліоми було виконано за допомогою внутрішньомозкової стереотаксичної імплантації щурячих клітин гліоми С6 в область смугастого тіла щура. Щурам вводили внутрішньоочере- 
винно 20 \% ДМСО (C6R1) або 5 мг/кг цисплатин (C6R4CIS i C6R5CIS) три рази на тиждень. Після 10 ін'єкцій, клітини гліоми були вилучені і поміщені в ростове середовище для подальшого аналізу in vitro. Зміни кількості копій хромосомних локусів було проаналізовано за допомогою порівняльної геномної гібридизації, аналіз проліфераціїздійснювали прямим підрахунком клітин в гемоцитометрі, а ефективність формування колоній (ЕФК) - аналізом росту в м'якому агаpi. Результати. Ніяких істотних змін числа копій хромосомних локусів, проліферації та ЕФК між лініями C6R4CIS, C6R5CIS i C6R1 не спостерігалося. Однак C6R5CIS, але не C6R4CIS лінія знизила проліферацію при порівнянні з C6R1. Цікаво, що клітинні лінії C6R4CIS, C6R5CIS i C6R1 мають нижчий рівень проліферації та ЕФК при порівнянні з вихідною батьківською лінією С6. Висновки. Незважаючи на численні повідомлення про дестабілізуючий вплив цисплатину на геном і фенотип клітин, терапія цисплатином С6 гліоми щура in vivo не вплинула на геномну стійкість, ЕФК та мало суперечний вплив на проліферацію клітин in vitro. Мікрооточення щурячого мозку потенційно може впливати на ростові характеристики пухлинних клітин гліоми.

К л юч о в і с л о в а: анеуплоїдія, хромосомна нестабільність, лікарська стійкість, еволюція пухлини, гетерогенність.

\section{Терапия цисплатином клеток С6 глиомы} крысы in vivo не повлияла на изменения числа копий хромосомных локусов и паттерн роста выделенных из опухоли резистентных клеток

А. А. Степаненко, В. П. Баклаушев, Е. С. Васецкий, В. В. Дмитренко

Цель. Проверить, влияет ли терапия цисплатином С6 глиомы крысы in vivo на изменения числа копий хромосомных локусов, пролиферацию и эффективность образования колоний цисплатин-нечувствительными клетками. Методы. Моделирование глиомы было выполнено с помощью стереотаксической имплантации аллогенных крысиных клеток глиомы С6 в область каудопутамена. Крысам с экспериментальной глиомой вводили внутрибрюшинно $20 \%$ ДМСО (C6R1) или 5 мг/кг цисплатин (C6R4CIS и C6R5CIS) три раза в неделю. После 10 инъекций, клетки глиомы были изъяты и помещены в ростовую среду для дальнейшего анализа in vitro. Изменение числа копий хромосомных локусов было проанализировано с помощью сравнительной геномной гибридизации, анализ пролиферации осуществляли прямым подсчетом клеток в гемоцитометре, а эффективность образования колоний (ЭОК) - анализом роста в мягком агаpe. Результаты. Никаких существенных изменений числа копий хромосомных локусов и ЭОК между линиями C6R4CIS, C6R5CIS и C6R1 не наблюдалось. Однако C6R5CIS, но не C6R4CIS линия снизила пролиферацию при сравнении с C6R1. Интересно, что клеточные линии C6R4CIS, C6R5CIS5 и C6R1 имеют более низкий уровень пролиферации и ЭОК, чем исходная родительская линия С6. Выводы. Несмотря на многочисленные сообщения о дестабилизирующем влиянии цисплатина на геном и фенотипи клеток, терапия цисплатином С6 глиомы крысы in vivo не повлияла на геномную устойчивость, ЭОК и оказывала противоречивое действие на пролиферацию in vitro. Микроокружение крысиного мозга потенциально может влиять на ростовые характеристики опухолевых клеток глиомы.

Кл юче в ы е с л о в а: анеуплоидия, хромосомная нестабильность, терапевтическая резистентность, эволюция опухоли, гетерогенность.

Received 03.02.2015 